Revista Brasil. Bot., V.31, n.3, p.453-456, jul.-set. 2008

\title{
A new species of Bulbophyllum Thouars (Orchidaceae) from Minas Gerais, Brazil
}

\author{
ERIC DE CAMARGO SMIDT ${ }^{1,2,4}$ and EDUARDO LEITE BORBA ${ }^{3}$
}

(received: January 01, 2008; accepted: June 12, 2008)

\begin{abstract}
A new species of Bulbophyllum Thouars (Orchidaceae) from Minas Gerais, Brazil). During the taxonomic revision of the Neotropical Bulbophyllum (Orchidaceae) species, a new species was discovered from Bom Sucesso, Minas Gerais State, described and illustrated here as B. hatschbachianum E. C. Smidt \& Borba. This species belongs to the Neotropical section Xiphizusa (Rchb. f.) Cogn. and posses a lip epichile completely different from the related species. It is closely to B. plumosum (Barb. Rodr.) Cogn. due to its vegetative morphology, but has different flower size, color and lip epichile. In B. plumosum the epichile is thin, longer and wider than the hipochile. In B. hatschbachianum the epichile is fleshy, shortest than the hipochile, thin, and sharply narrower than the hipochile. The flowers of this new species is similar to the Mexican B. solteroi R. González, but the general morphology of the lip, trichome size and the geographical distribution clearly distinguishes apart the two species.
\end{abstract}

Key words - Bulbophyllum, Cerrado, Orchidaceae, taxonomy

RESUMO - (Uma nova espécie de Bulbophyllum Thouars (Orchidaceae) de Minas Gerais, Brasil). Durante a revisão taxonômica das espécies neotropicais de Bulbophyllum (Orchidaceae), uma nova espécie foi descoberta em uma coleta proveniente de Bom Sucesso, Estado de Minas Gerais, descrita e ilustrada, aqui, como B. hatschbachianum E. C. Smidt \& Borba. A espécie pertence à seção Neotropical B. sect. Xiphizusa (Rchb. f.) Cogn. e possui um labelo com epiquílio completamente diferente das demais espécies da seção. É próxima de B. plumosum (Barb. Rodr.) Cogn. considerando-se a morfologia vegetativa, mas difere desta pelo tamanho e coloração da flor e pelo epiquílio do labelo. Em B. plumosum o epiquílio é delgado, maior e mais largo que o hipoquílio. Em $B$. hatschbachianum o epiquílio é carnoso, mais curto que o hipoquílio, delgado e nitidamente mais estreito que o hipoquílio. As flores da nova espécie podem ser comparadas às da espécie mexicana $B$. solteroi R. González, mas a morfologia geral do labelo, o tamanho dos tricomas, e a distribuição geográfica tornam fácil a distinção entre as duas espécies.

Palavras-chave - Bulbophyllum, Cerrado, Orchidaceae, taxonomia

\section{Introduction}

The Pantropical Bulbophyllum Thouars is the largest orchid genus, including over 1,700 species (Vermeulen 1991, Dressler 1993, Sieder et al. 2007). Most of its species occur in the Old World, mainly in southeastern Asia, and nearly 100 names are proposed for the Neotropics, of which 60 species could be recognized (Smidt 2007). In the most recent inventory of Brazilian orchids, Pabst \& Dungs (1975) cited 54 species for Brazil. However, with the addition of some recently described species, new occurrences for this country (e.g., Borba

1. Universidade Estadual de Feira de Santana, Departamento de Ciências Biológicas, Laboratório de Sistemática Molecular de Plantas, Rodovia BR 116, km 03, 44031-460 Feira de Santana, BA, Brazil.

2. Endereço atual: Instituto de Botânica, Seção de Curadoria do Herbário, Caixa Postal 4005, 01061-970 São Paulo, SP, Brazil.

3. Universidade Federal Minas Gerais, Instituto de Ciências Biológicas, Departamento de Botânica, Laboratório de Sistemática, Avenida Antônio Carlos, 6627, Pampulha, 31270-901 Belo Horizonte, MG, Brazil.

4._Corresponding author: ecsmidt@yahoo.com.br
\& Smidt 2004, Fraga \& Smidt 2004, Ribeiro et al. 2005, Smidt \& Borba 2007b), and the proposal of new synonyms, 47 species, two subspecies and one nothospecies are considered to occur in Brazil (Smidt 2007).

The State of Minas Gerais comprises the region with the highest diversity of the genus, including 34 species, of which eight (24\%) are endemics. This high diversity is probably due to the occurrence of Atlantic Rain Forest and Cerrado vegetational edges and to the high topographical diversity, including several mountain ranges presenting campo rupestre vegetation and valleys with high humidity (Smidt \& Borba 2007a, Smidt et al. 2007).

Twenty three Bulbophyllum species belong to section Xiphizusa (Rchb. f.) Cogn., characterized mainly by the discoid small aggregated pseudobulbs and the long scape with distically disposed flowers on the thin rachis. The flowers have a conspicuous jugae (ovary tissue extension) at the petals base, long fused lateral sepals in most species, petals oblong to narrow lanceolate, which are pilose in most species with long hairs in the margins. 
The lip is trilobed, with lateral lobes erect, obtuse, and sometimes pilose, the disc (region on the lip between the lateral lobes, sometimes extended to the apex) is smooth or with a longitudinal ridge at the middle. The epichile may be thin and membranaceous or hardly thick. In some species the epichile is sessile at the base or more usually constricted, the limb may be flat or concave, and normally smooth or rarely pilose in the margin and in the face. Species from sect. Xiphizusa are mainly epiphytic in forested and Cerrado areas, and occasionally lithophytic in campo rupestre vegetation, such as $B$. plumosum (Barb. Rodr.) Cogn. and B. gladiatum Lindl. This section presents an interesting disjunction between southeastern Brazil and the Andean mountains in Venezuela throughout Peru, with one species endemic to Mexico.

In the course of a revision of the Neotropical Bulbophyllum species, we found a new species which belongs to section Xiphizusa, with a particular suite of characters described as follows.

\section{Results and discussion}

Bulbophyllum hatschbachianum E. C. Smidt \& Borba, $s p$. nov. Type: BRAZIL. Minas Gerais: Bom Sucesso, $18^{\circ} 35^{\prime}$ S, 455' W, 3-XI-1991 (fl.), E.T. Neto \& M.S. Werneck 715 (holotype BHCB).

Figure 1

B. plumoso vegetativus affine, florem differt. B. solteroi aemulans, differt hipoquilis trichomate brevissimus, epiquilis brevis cum callus differens.

Mostly epiphytic herbs. Rhizome inconspicuous. Pseudobulbs 1.2-1.5 × 1.3-1.5 cm, deltoid, transversally elliptic, brownish, rugose, monophyllous. Leaves 5.0-6.0 $\times$ 0.8-1.2 cm, plane, oblong to elliptic, base constricted, apex acute, coriaceous. Inflorescence raceme, $12.0-15.0 \mathrm{~cm}$ long, erect, scape cylindrical, basal bract of the scape inconspicuous, the others not imbricate; rachis $4.0-5.0 \mathrm{~cm}$ long, thin, pendulous, 10-12 flowers arranged distichously, anthesis simultaneous. Flowers ressupinated by rachis bending, membranaceous, jugae present and very conspicuous. Sepals erect, smooth, purple; dorsal sepal $5.0 \times 1.5 \mathrm{~mm}$, lanceolate, concave, 3-nerved, margin glabrous, apex acuminate; lateral sepals $5.0 \times 2.0 \mathrm{~mm}$, lanceolate, fused from base up near to the apex, 3-nerved, margin glabrous, apex acute. Petals $2.0 \times 1.2 \mathrm{~mm}$, lanceolate, erect, flat, 1-nerved, base sessile, dilated, apex acute, margin ciliate with long linear purple hairs, whitish, translucid, mid-vein purple. Lip $4.0 \times 1.2 \mathrm{~mm}$, trilobed, purple, differentiated in epichile and hypochile; hypochile with lateral lobes erect, obtuse, hairy, hairs very short, apex attenuate, disc between the lateral lobes with a smooth discrete ridge; epichile fleshy, short, linearlanceolate, margin glabrous, base constrict, apex acute, purplish. Column glabrous adaxially; stellidia present, erect, entire, apex acute; teeth present, erect, apex acute; column foot short, stigma large; anther versatile, 3-globose. Fruit $5.0 \times 4.0 \mathrm{~mm}$, smooth.

Etymology - This species is named in honor to Gerdt Hatschbach, one of the leading Brazilian botanic collectors in activity, herbarium curator of the "Museu Botânico Municipal de Curitiba" (MBM) and responsible for dissemination of the knowledge of Brazilian biodiversity. During his 65 years dedicated to Botany, G. Hatschbach has collected more then 77,000 specimens, ca. 500 of them being new species for the science, with ca. 140 named on his honor, including 14 orchids.

Distribution - Endemic to Minas Gerais State, Brazil, growing in Cerrado as epiphytic, ca. 950 meters of altitude. It is known from the type only.

Conservation status - Insufficient data. Species recently discovered, in a place with few collections. More field studies are necessary to frame it in some conservation category. However, B. hatschbachianum is likely to have a restricted geographical distribution, since it occurs in one of the best collected states of Brazil. The discovery of a new orchid species in a such well collected region, certainly emphasizes the importance of continuous field trips and suggests SE Brazil may present a higher diversity of Bulbophyllum species than previously thought.

Bulbophyllum hatschbachianum is a species with peculiar morphology, whose lip cannot be compared directly with any other species of the genus in the Neotropics. It is closely related to B. plumosum (Barb. Rodr.) Cogn. due to its general vegetative morphology, but the flower size, color and distinctive epichile make its recognition easy. In B. plumosum the epichile is thin, longer and wider than the hipochile. In B. hatschbachianum the epichile is fleshy, shortest than the hipochile, thin, and sharply narrower than the hipochile. Bulbophyllum solteroi R. González, a Mexican species, also possess hipochile of the same size or slightly larger than the epichile, however its epichile has the same width or is slightly wider than the hipochile and possess a different morphology of the callus. The trichomes in the margin of the hipochile are very short, being discernible only with the aid of a magnifying glass, unlike its closest species, which possess clear tricomes along the hipochile margin. 


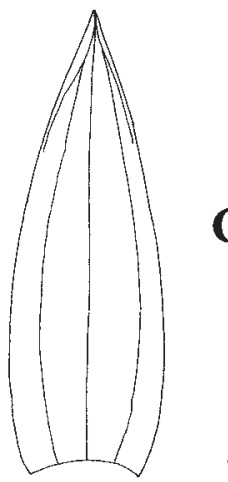

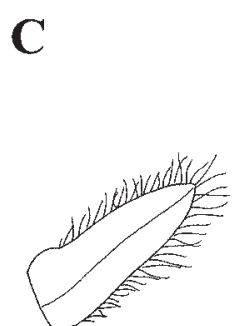

E

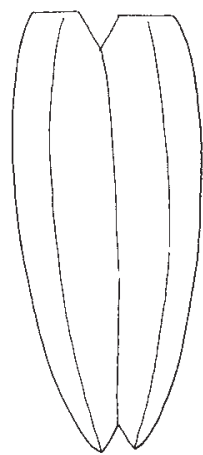

D
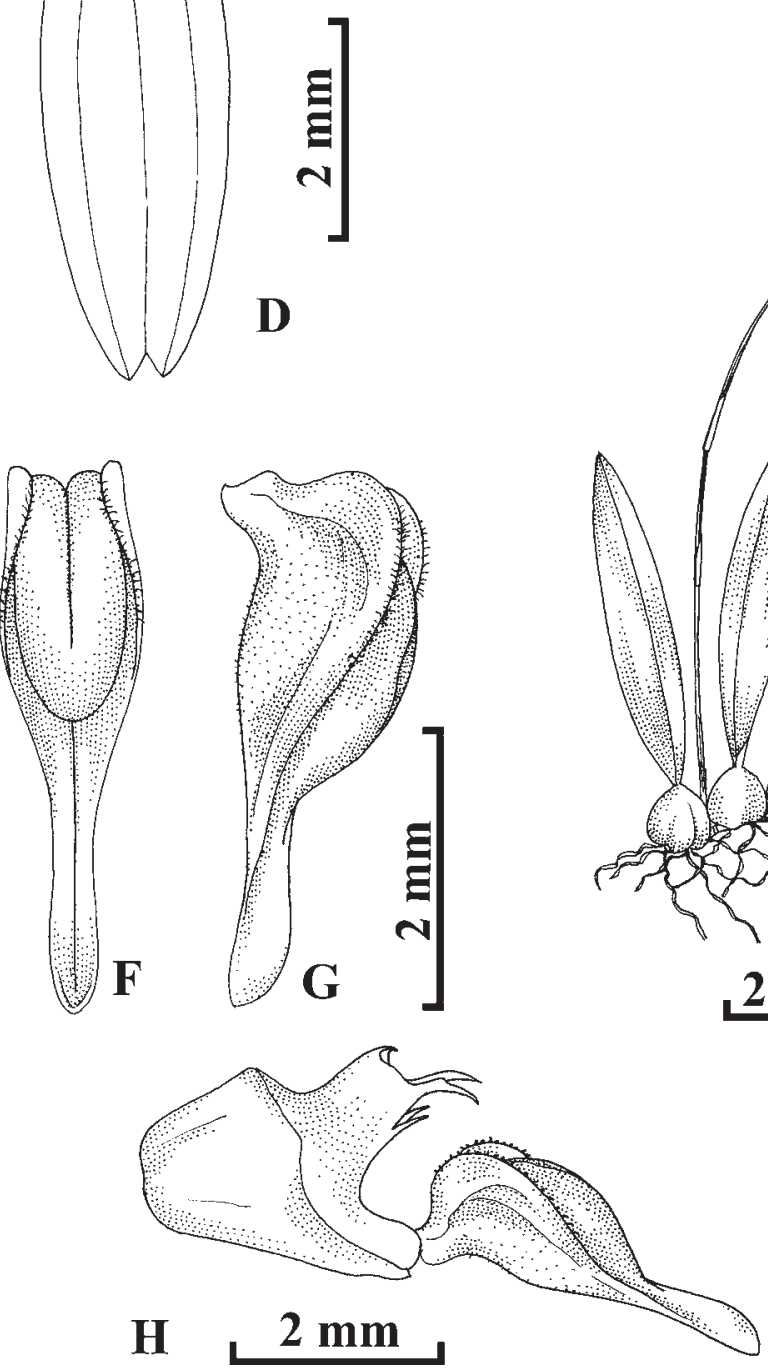
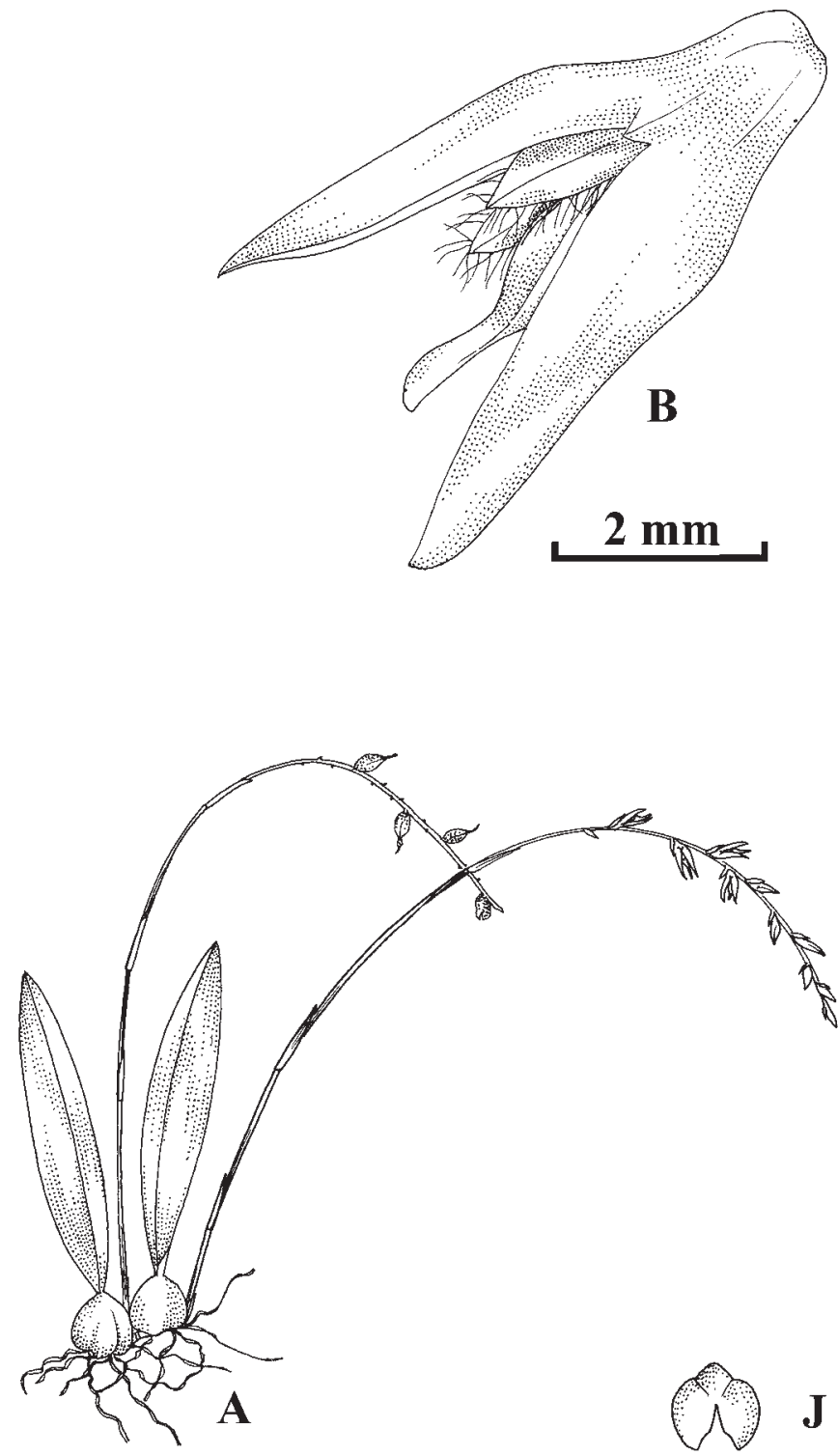

$2 \mathrm{~cm}$

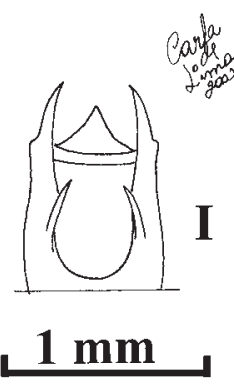

Figure 1. Bulbophyllum hatschbachianum E. C. Smidt \& Borba. A. Habit. B. Flower, side view. C. Dorsal sepal. D. Fused lateral sepals. E. Petal. F. Lip, upper view. G. Lip, side view. H. Lip and column, side view. I. Columm, ventral view. J. Anther. (Neto \& Werneck 715; by Carla Lima). 
The flowering period is November. There is no information on the pollination and reproductive system of this species.

Acknowledgments - We thank to Fapesb (BOL 0368A/05 and APR 340/04) and American Orchid Society for financing the first author's study and to the Postgraduate Program in Botany of the Universidade Estadual de Feira de Santana (UEFS). E. L. Borba is supported by a grant (PQ2) from CNPq (Conselho Nacional de Desenvolvimento Científico e Tecnológico).

\section{References}

BORBA, E.L. \& SMIDT, E.C. 2004. Bulbophyllum filifolium Borba \& Smidt (Orchidaceae), a new species from Southeastern Brazil. Novon 14:29-32.

DRESSLER, R.L. 1993. Phylogeny and classification of the orchid family. Dioscorides Press, Porland.

FRAGA, C.N. \& SMIDT, E.C. 2004. Bulbophyllum arianae (Orchidaceae), a new species from Atlantic Rain Forest of Espírito Santo, Brazil. Harvard Papers in Botany 9:7-9.

PABST, G.F.J. \& DUNGS, F. 1975. Orchidaceae Brasiliensis, Kurt Schmerson, Hildesheim. v.1.
RIBEIRO, P.L., BORBA, E.L. \& TOSCANO-DE-BRITO, A.L.V. 2005. O gênero Bulbophyllum Thouars (Orchidaceae) na Chapada Diamantina, Bahia, Brasil. Revista Brasileira de Botânica 28:423-439.

SIEDER, A., RAINER, H. \& KIEHN, M. 2007. CITES checklist for Bulbophyllum and allied taxa (Orchidaceae). 319p. - Botanical Garden, University of Vienna. http://www. cites.org/common/com/NC/tax_ref/Bulbophyllum. pdf (acessed in 2007).

SMIDT, E.C. 2007. Filogenia e revisão taxonômica de Bulbophyllum Thouars ocorrentes no Neotrópico. Tese de doutorado, Universidade Estadual de Feira de Santana, Feira de Santana.

SMIDT, E.C. \& BORBA, E.L. 2007a. Bulbophyllums in Brazil: collection history and distribution. Orchids 76:130-133.

SMIDT, E.C. \& BORBA, E.L. 2007b. A new Bulbophyllum species (Orchidaceae), named in honor of F.C. Hoehne. Orchids 76:934-936.

SMIDT, E.C., SILVA-PEREIRA, V., BORBA, E.L. \& VANDEN BERG, C. 2007. Richness, distribution and important areas to preserve Bulbophyllum in the Neotropics. Lankesteriana 7:107-113.

VERMEULEN, J.J. 1991. Orchids of Borneo, v.2 Bulbophyllum. Royal Botanic Gardens, Kew. 